\title{
ABHD6-aren inhibizioaren azterketa birmielinizazioa bultzatzeko kuprizonaren desmielinizazio primarioaren aniamalia-ereduan
}

\author{
(Examining ABHD6 inhibition to promote remyelination \\ the cuprizone model of primary demyelination)
}

\author{
Ana Bernal-Chico*1,2,3, Andrea Manterola ${ }^{1}$, Susana Mato ${ }^{1,2,3,4}$ \\ ${ }^{1}$ Neurozientziak Saila, Medikuntza eta Erizaintza Fakultatea (UPV/EHU) \\ ${ }^{2}$ Achucarro Basque Center for Neuroscience \\ ${ }^{3}$ Centro de Investigación Biomédica en Red sobre Enfermedades Neurodegenerativas \\ (CIBERNED) \\ ${ }^{4}$ Biocruces, Bizkaia
}

\begin{abstract}
LABURPENA: Esklerosi anizkoitza (EA) nerbio-sistema zentralaren (NSZ) hanturazko gaixotasun desmielinizatzailea da. Gaixotasunaren etiologia zehatza ezagutzen ez den arren, jakina da oligodendrozitoen heriotzarekin eta neuronen endekapenarekin erlazionatutako hantura-lesioak agertzen direla. Gertaera horiek dira, hain zuzen ere, ezgaitasuna eragiten dituztenak pazienteengan. Hala ere, mielinaren birsortze partziala gertatzen da, eta hobekuntza hori bultzatzeko estrategiak dira gaur egun bilatzen direnak. Endokanabinoide-sistemak EAren sintomatologia murrizteko potentziala duela frogatu dute urteetan zehar egindako ikerketek. Zentzu horretan, 2-arakidonoilglizerolaren (2-AG) degradazioa inhibitzeak dirudi estrategia terapeutikorik onena. Monoazilglizerol lipasa (MAGL) entzimak 2-AG-aren proportzio handiena degradatzen du NSZn. Entzima horren inhibizioak, bai desmielinizazioan bai konponketan onurak sustatzen dituen arren, CB1 hartzaileen desentsibilizazioa ere eragiten du. Nahiz eta ABHD familiako hidrolasa 6-k (ABHD6) 2-AG-aren kopuru txikiagoa degradatzen duen egoera basaletan, hantura-egoeretan proportzio handiagoa degradatu egiten du. Horregatik, hanturazko testuinguruetan ABHD6-aren inhibizioa proposatzen da 2-AG mailak igotzeko efektu ez desiragarriak ekiditen diren bitartean. Asmo horrekin, ABHD6-aren inhibitzaile espezifiko baten (KT182) birmielinizazio ahalmena aztertu dugu EA-ren animalia-eredu batean.
\end{abstract}

HITZ GAKOAK: esklerosi anizkoitza, birmielinizazioa, hantura, endokanabinoideak, KT182.

\begin{abstract}
Multiple sclerosis (MS) is an inflammatory demyelinating disease of the nervouse central system (CNS). Although the ethiology of the disease remains unknown, of the main hallmarks is the appearance of inflammatory lesions related to the death of oligodendrocytes and neurodegeneration. Those events are, indeed, the cause of disability in the patients. However, there is a partial recovery of the myelin, and nowadays the efforts are focused on finding strategies to enhance this repair. During the last years, numerous researches have shown the potential of the endocannabinoid system to reduce the symptomatology of MS. In this sense, the inhibition of the degradation of 2-arachidonoylglycerol (2-AG) seems the most promising strategy. Monoacylglycerol lipase (MAGL) degrades the majority of the 2-AG in the CNS. Although the blockade of this enzyme protects against demyelination and promotes remyelination, it also induces desensitization of CB1 receptors. Even though in basal conditions alpha/beta-Hydrolase containing domain 6 (ABHD6) hydrolyses a small quantity of 2-AG, it degrades a bigger amount under inflammatory conditions. Thus, ABHD6 inhibition is proposed in inflammatory contexts in order to increase 2-AG levels while avoiding side effects. With this aim, we study the remyelination potential of KT182, a specific ABHD6 inhibitor, in an animal model of MS.
\end{abstract}

KEYWORDS: multiple sclerosis, remyelination, inflammation, endocannabinoids, KT182.

* Harremanetan jartzeko / Corresponding author: Ana Bernal-Chico. Neurozientziak saila, Medikuntza eta Erizaintza Fakultatea, UPV/EHU, Sarriena auzoa, z/g (48940 Leioa, Bizkaia, Euskal Herria). - ana.bernal@ehu.eus - https://orcid.org/00000002-7913-2350.

Nola aipatu / How to cite: Bernal-Chico, Ana; Manterola, Andrea; Mato, Susana (2020). «ABHD6-aren inhibizioaren azterketa birmielinizazioa bultzatzeko kuprizonaren desmielinizazio primarioaren aniamalia-ereduan»; Ekaia, 38, 2020, 241-257. (https://doi.org/10.1387/ekaia.21355).

Jasoa: 31 abenduak, 2019; Onartua: 16 apirilak, 2020.

ISSN 0214-9001 - eISSN 2444-3255 / (c) 2020 UPV/EHU 


\section{SARRERA}

Mielina nerbio-zelulen axoiak estaltzen dituen izaera koipetsuko mintz zelularra da, oligodendrozitoek osatzen dutena. Ezinbestekoa da nerbio bulkaden garraioa era egokian gerta dadin. Esklerosi anizkoitza (EA) nerbio-sistema zentraleko (NSZ) hanturazko gaixotasun kronikoa da, desmielinizazio-fokuak sortzen dituena. EA oso konplexua da, baina desmielinizazioa, hantura eta endekapen neuronal/axonala dira gaixotasunaren ezaugarririk nagusienak [1]. EAren etiologia argi ezagutzen ez den arren, gehien onartua dagoen teoriaren arabera, gaixotasuna linfozito autoreaktiboek barrera hematoentzefalikoa zeharkatzen dutenean hasten da NSZko gliaren aktibazioa eta neuroendekapena eragiten [2]. Hala ere, azken urteetan oligodendrozitoen heriotza primarioak eta desgaitasun axonal goiztiarrak garrantzia hartu dute EAren sortze eta progresioa eragin dezaketen mekanismo etiopatologiko alternatibo gisa.

Sistema immunearen erregulazio-akatsa EAn gertatzen den NSZren kaltearen bitartekari nagusitzat hartzen da [3]. Prozesu horren eragile nagusiak zelula dendritikoak dira; barrera hematoentzefalikoa zeharkatu eta zitokina desberdinak askatuz, T zelulen diferentziazioa eragiten dute. Hala ere, hainbat gaixotan, lesioa sortu berrietan oligodendrozitoen apoptosi goiztiarra eta mikroglien aktibazioa deskribatu dira zelula immuneen absentzian $[4,5]$. Aurkikuntza horren arabera, autoimmunitatea, EA duten paziente batzuen kasuan gutxienez, oligodendrozitoen apoptosi primarioaren osteko gertakizun bat izan liteke.

Lesio gehienek kronikoki desmielinatuta jarraitzen duten arren, kasu batzuetan mielinaren berezko «konponketa» gertatzen da. Lesio horiei «shadow plaques» deitzen zaie [6]. Birmielinizazioa mielinaren berreskuratzea eragiten duen prozesu birsortzailea da. Erantzun fisiologiko hori oligodendrozitoen zelula aitzindarien (OPC) errekrutamenduari, ugalketari eta oligodendrozito heldu mielinatzaileetan desberdintzeko gaitasunari esker gertatzen da [7, 8]. OPCen aktibazioa eta errekrutamendua eragiten dituen mekanismoak ez dira oraindik guztiz ezagutzen. Deskribatu denaren arabera, mikrogliak dira NSZko ehunen kaltea hautematen duten lehen zelulak. Aktibatzen direnean, seinalizazio-molekula ezberdinak askatzen dituzte eta NSZko astrozitoak aktibatzen dira; astrozito horiek, erantzun gisa, faktore ezberdinak askatu eta OPCen modulazioa eragiten dute [7]. Hala ere, birmielinizazioa denborarekin ez-eraginkor bihurtzen dela ikusi da, eta horrek endekapen neurologikoaren areagotzea bultzatzen du [9]. Hainbat ikerketaren arabera, birmielinizazio-ahalmenaren galera hori eremu kaltetuetan OPCek diferentziatzeko gaitasuna galtzen dutelako gertatzen da [8] Horregatik, zelula horien diferentziazioa bultza dezaketen estrategia terapeutikoak garatzea oso gai garrantzitsua bihurtu da EAren inguruko ikerkuntzan. 
EAren alderdi ezberdinak ikertu ahal izateko, hainbat animalia-eredu ditugu eskuragai. Birmielinizazioa bultzatzeko estrategiak aztertzeko, kuprizonaren eredu toxikoa zabalki erabiltzen da [10]. Kuprizona (bis-cyclohexanone-oxaldihydrazone) kupre kelatzaile bat da, era selektiboan oligodendrozito helduen heriotza eragiten duena, ondorioz desmielinizazio primarioa eragiten gorputz kailukaran batez ere. Eredu honetan NSZko gliaren aktibazioa ikus daiteke ia $\mathrm{T}$ zelulen agerpenik gabe, barrera hematoentzefalikoaren integritatea mantentzen delako. Oligodendrozitoen apoptosia kuprizonak mitokondriei eragindako kalteagatik gertatzen da. Desmielinizazioa eragiteko, kuprizona dietan gehitzen da; oso desmielinizazio errepikakorra sortzen da garuneko hainbat lekutan. 5-6 asteko etengabeko tratamenduak erabateko desmielinizazioa eragiten du. Ondoren, janari normalera itzuliz gero, birmielinizazio-fase bat hasiko da. Ezaugarri horrek birmielinizazioa bultza dezaketen estrategia terapeutikoak frogatzea ahalbidetzen du.

Garuneko endokanabinoide-sistema hainbat funtzio doitzen dituen sistema neuromodulatzailea da: besteak beste, mugimendua, kognizioa, oroimena, aldartea, gorputzaren tenperatura edota jangura.

Orain dela 30 urte, lehenengo hartzaile kanabinoidea arratoien garunkortexetik klonatzea lortu zen, eta 1 kanabinoide-hartzailea $\left(\mathrm{CB}_{1}\right.$ hartzailea) izena eman zitzaion [11]. Laster, bigarren hartzaile bat identifikatu zen arratoietan [12], eta horri 2 kanabinoide-hartzailea iritzi zioten $\left(\mathrm{CB}_{2}\right.$ hartzailea).

CB1 hartzailea ugaztunen garuneko GPCR-rik ugariena da. Distribuzio zelularrari dagokionez, batik bat, mota ezberdinetako neurona heldue$\tan$ adierazten da [13-15]. Hartzaile gehienak axoien bukaera presinaptikoetan agertzen dira; neurotransmisoreen liberazioa negatiboki doitzen da, eta, horrela sinapsien homeostasia bermatzen da [16]. $\mathrm{CB}_{1}$ hartzaileen presentzia zelula glialetan ere deskribatu da, bai astrozitoetan $[17,18]$, mikroglian [19] eta baita oligodendrozitoetan ere [20, 21].

$\mathrm{CB}_{2}$ hartzaileei dagokienez, immunitate-sistema periferikoko zelula eta ehunak dira proteina hau gehien agertzen dutenak; kanabinoideen efektu immunomodulatzaileen bitartekari nagusiak dira [22, 23]. NSZ osasuntsuan, eztabaida dago ea $\mathrm{CB}_{2}$ hartzaileak agertzen diren edo ez [24]. Hala ere, NSZn hanturazko egoeretan, mikrogliek $\mathrm{CB}_{2}$ hartzailea adierazten dutela deskribatu da [25].

Endokanabinoideak mintz zelularreko osagarriak erabiliz sintetizatzen diren mezulari lipidikoak dira. Bi dira endokanabinoide nagusiak: $\mathrm{N}$-arakidonoiletanolamina (anandamida, AEA) [26], agonista partziala dena; eta 2-arakidonoilglizerola (2-AG) [27], agonista oso gisa jokatzen duena [22]. AEA sintetizatzen duen entzima nagusia $\mathrm{N}$-azil fosfatidil etanolamina- fosfolipasa D-a (NAPE-PLD) da (Cadas et al. 1996). 
2-AG-aren kasuan diazilglizerol lipasa $\alpha$ eta $\beta$ (DGL $\alpha / \beta)$ entzimak dira sintesiaren arduradunak $[28,29]$. AEA hidrolizatzen duen entzima, gantz-azidoen amido hidrolasa (FAAH) da [30]. Bestalde, 2-AG-aren entzima hidrolizatzaile nagusia monoazilglizerol lipasa (MAGL) da [31], 2-AG guztizkoaren \% 85 inguru hidrolizatzen duena [32]. Neuronetan adierazteaz gain, FAAH eta MAGL entzimak zelula glialetan adieraztea ere deskribatu da [33].

MAGLaz gain, ABHD familiako hidrolasa 6 eta $12(\alpha / \beta$-hydrolase domain containing 6 and 12, ABHD6/ABHD12) 2-AG-a hidrolizatzeko gai diren beste bi entzima dira [34]. ABHD6-a immunitate-sistemako zeluletan, hesteetan eta garunean maila altuan agertzen da (Human Protein Atlas). NSZri dagokionez, ABHD6-a gehienbat bukaera postsinaptiko glutamatergikoetan agertzen da, baina baita bukaera GABAergikoetan edo astrozito eta mikroglietan ere [35]. Baldintza fisiologikoetan, 2-AGaren guztizko kopuruaren \%4 inguru hidrolizatzen du [32]. Hainbat ikerketak erakutsi dutenaren arabera, NSZ kaltetuta daukaten karraskarietan ABHD6-aren agertze-maila igotzeaz gain, entzima hau farmakologikoki inhibitzeak efektu onuragarriak eragiten ditu [36-38]. Horren arabera, baldintza fisiologikoekin alderatuta, uste da ABHD6-ak 2-AG-aren guztizko kopuruaren proportzio altuagoa hidrolizatzen duela zenbait hantura-prozesutan.

Kanabisarekin automedikatzen ziren gaixoek erasoen maiztasunean, espastizitatean eta dardaren kontrolean zituzten hobekuntzetan oinarrituta [39], kanabinoideek EAn izan dezaketen potentzial terapeutikoa luzaroan aztertu da. Horrela, exogenoki emandako agonista kanabinoideek neuroendekapena, desmielinizazioa eta hantura murriztua eta birmielinizazioa bultzatzen dituztela ikusi da [40-43]. Hala ere, ikerketa desberdin askok erakutsi dutenaren arabera, kanabinoide exogenoen erabilerak efektu ez-desiragarriak sortzen ditu, horien artean psikoaktibitatea eta oroimen arazoak. Efektu horiek garuneko $\mathrm{CB}_{1}$ hartzaile guztiak modu ez-espezifikoan aktibatzeagatik agertzen dira. Beraz, EAren inguruko gaur egungo ikerketen helburua $\mathrm{CB}_{1}$ eta $\mathrm{CB}_{2}$ hartzaileen aktibazioak dakartzan efektu onuragarriak mantendu eta ez-desiragarriak murriztuko dituzten terapien garapena da. Testuinguru horretan, 2-AG-a degradatzen duten entzimen inhibizioaren bitartez endokanabinoide horren kontzentrazioa leku zehatzetan handitzea proposatu da estrategia itxaropentsu gisa.

Animalia-ereduetan eginiko hainbat ikerketak MAGLaren inhibitzaileek hantura eta kalte neurologikoak murrizteko eta birmielinizazioa bultzatzeko gaitasuna dutela frogatu dute [20, 44-46]. Zoritxarrez, MAGL entzima luzaroan inhibitzeak efektu ez-desiragarriak ere eragiten ditu: garuneko $\mathrm{CB}_{1}$ hartzaileen desentsibilizazioa (erantzunik eza edo gutxitua, gehiegizko estimulazioaren ondorioz) eta tolerantzia funtzionala (erantzun 
bera lortzeko agonista kopuru handiagoa behar denean), besteak beste [47]. Horregatik guztiagatik, MAGL entzima inhibitzen duten farmakoen erabilera zalantzan jartzen da.

Beste ikerketa batzuetan, proposatzen da, ABHD6 entzima inhibitzeak bai sistema periferikoan bai NSZn 2-AG kontzentrazioak era finean doitzea ahalbidetzen duela; doitze horrek testuinguru patologikoetan efektu onuragarriak izaten ditu. Ikusi da, bereziki, ABHD6-a farmakologikoki inhibitzeak, sinapsietan eta makrofago periferikoetan 2-AG-aren kontzentraziomailen igoera eraginez, efektu antiepileptikoak eta hanturaren aurkakoak sortu ditzakeela [48, 49]. Horrez gain, frogatu da efektu babesgarri horiek dosi kronikoen ostean mantendu egiten direla efektu ez-desiragarririk eragin gabe [50].

Berriki, ABHD6 entzima inhibitzeak EAren testuinguruan efektu onuragarriak dituela erakusten duten lanak argitaratu dira. Esaterako, WWL70 inhibitzaile sistemikoa erabiliz, ikusi da saguak EAEaren (entzefalomielitis autoimmune esperimentala) aurka babestuta daudela, hanturaren aurkako efektu indartsuak erakutsiz [51]. Hala ere, ikertzaile talde bereko kideek WWL70-ak mikroglietan ABHD6-arekin zerikusirik ez duten mekanismoen bitartez, prostaglandinen produkzioa murrizten duela deskribatu dute, eta inhibitzailearen erabilerak in vivo eragindako onurak mekanismo honekin erlazionatuta egon daitezkeela proposatu da [52]. Gure taldean berriki aurkitutakoaren arabera, ABHD6-a blokeatzeak barrera hematoentzefalikoa zeharkatzeko gai den KT182 inhibitzaile espezifikoarekin hanturazko erantzuna murrizten du desmielinizazio primarioan [37]. Gainera, inhibitzailearen administrazio profilaktikoak mielina babesteko gaitasuna ere badauka kuprizonaren animalia-ereduan [37]. Hala ere, EAE eredu autoimmunean, hasieran babesa eragiten den arren, fase kronikoan onurak ez dira detektagarriak [38]. Mielinaren babesean eta konponketan MAGLaren inhibizioak dituen efektu onuragarriak eta ABHD6 entzimak hanturatestuinguruetan parte hartzea kontuan hartuz, KT182-aren birmielinizazio ahalmena aztertu nahi izan dugu.

\section{MATERIALAK ETA PROZEDURA ESPERIMENTALAK}

\subsection{Animaliak}

Kuprizona bidezko desmielinizazio/birmielinizazio animalia-eredurako C57BL/6 sagu basatiak erabili ziren, Charles River-en (Bartzelona, Espainia) erosiak. Animalia guztiak baldintza estandarretan (12 orduko argi/ ilunpe zikloak) eta ura eta janaria ad libitum izanez mantendu ziren. Prozedura guztiek helburu zientifikoekin erabilitako animaliak babesteko Europako Zuzentaraua bete zuten (2010/63/UE), eta Euskal Herriko Unibertsitateko AEEB batzordeak (Animaliekin egiten den Esperimentaziorako 
Etika Batzordea) eta Gipuzkoako Diputazioak onetsi eta kontrolatu zituzten. Animalien sufrimendua eta erabili beharreko animalien zenbakia murrizteko esfortzu guztiak egin ziren.

\subsubsection{Kuprizona bidezko desmielinizazio primarioaren animalia-eredua}

Desmielinizazio primarioa 10 asteko saguei \%0,3 kuprizona (bis-ziklohexanona oxaldihidrazona; Sigma-Aldrich) zeraman ehotako sagubazka (Altromin, Lemgo, Alemania) 6 astez emanez eragin zen. Birmielinizazioa ikertzeko, kuprizona zuen janaria 6 astez eman ondoren, saguak dieta arruntera itzuli ziren bi astez. Toxikoa kenduta, birmielinizazio espontaneoa gertatzen da: mielina-maila partzialki berreskuratu eta hantura murriztu egiten da.

\subsection{ABHD6 entzimaren inhibitzailea}

ABHD6 entzimaren KT182 [4-[3'-(Hidroximetil)[1,1'-bifenil]-4-il]1H-1,2,3-triazol-1-yl](2-frenil-1-piperidinil)-metanona] izeneko inhibitzaile selektiboa Benjamin F. Cravatt doktorearen laborategian sintetizatu zen The Scripps Research Institutoan (La Jolla, CA, AEB), lehenago deskribatu izan den bezala [53]. Inhibitzaile honek barrera hematoentzefalikoa zeharkatzeko gaitasuna dauka.

\subsubsection{ABHD6 entzimaren inhibitzailearen administrazioa}

ABHD6 entzimaren KT182 inhibitzailea \%15 DMSO, \% 4,25 polietilen glikol 400 (Sigma-Aldrich), \% 4,25 Tween-80 (Sigma-Aldrich) eta $\%$ 76,5 disoluzio fisiologikoz osatutako eramailean disolbatu eta intraperitonealki txertatu zen $2 \mathrm{mg} / \mathrm{kg}$-ko dosian. Birmielinizazioa aztertzeko, 6 astez kuprizona irentsi zuten animalietatik, zoriz, talde bi aukeratu eta 2 astez egunero KT182 inhibitzailea edo eramailea txertatu zitzaien.

\subsection{Histologia eta analisi immunohistokimikoak}

\subsubsection{Saguen akabatzea eta ehunen prozesamendua}

Saguak ketamina/xilazina $\left(80 / 10 \mathrm{mg} / \mathrm{kg}\right.$; Imalgene $\left.{ }^{\circledR}\right)$ zeraman txerto intraperitoneal baten bitartez anestesiatu ziren. Ondoren, bihotz-zeharreko perfusioa egin zitzaien ponpa peristaltiko baten laguntzaz; lehendabizi, soluzio fisiologikoarekin, eta ondoren, 0,1 M PB-tan prestatutako $\% 4$ paraformaldehido zeraman disoluzio finkatzailearekin. Jarraian, garunak 3 orduz $\% 4$ paraformaldehidoan postfinkatu eta gau batez $\% 20$ sakarosan kriobabestu ziren. Azkenik, ehun horiek Tissue-Tek OCT-an (Electron Microscopy Sciences, Hatfield, PA, AEB) barneratu eta 
$-80{ }^{\circ} \mathrm{C}$-an gorde ziren. Garuneko $10 \mu \mathrm{m}$-ko sekzio koronalak CM3050S kriostatoa (Leica) erabiliz lortu ziren, eta $-20{ }^{\circ} \mathrm{C}$-an gorde ziren, harik eta erabili arte.

\subsubsection{Histologia}

Kuprizonarekin tratatutako saguen garunetako sekzio/ebaketa koronalak (bregma 1 eta -1 artean; Paxinos eta Franklin, 2012), Luxol Fast Blue (LFB) tindaketarekin markatu ziren mielina ebaluatzeko. Horretarako, ehunak gau batez $37-42{ }^{\circ} \mathrm{C}$-an, \% 95-eko etanola, \% 0,5 azido azetiko glazial eta \% 0,1 LFB solbente 38 (Sigma-Aldrich) zeramatzan disoluzio batean inkubatu ziren. Ondoren, sekzioak \% 0,01 litio karbonatoarekin (SigmaAldrich) tindugabetu ziren. Azkenik, alkohol-kontzentrazio desberdinetatik pasatuz (\% 70-\% 96-\% 100), ehunak deshidratatu, eta, jarraian, DPXrekin (Sigma-Aldrich) estali ziren.

\subsubsection{Immunofluoreszentzia eta immunoperoxidasa markaketak}

Ehunak \% 5 serum (NGS) eta \% 0,2 Triton X-100 zeramatzan TBSan blokeatu ziren ordubetez. Jarraian, zenabit antigorputz primarioz inkubatu ziren gau osoz $4{ }^{\circ} \mathrm{C}$-an: saguan egindako MBParen aurkako antigorputza (1:1000; BioLegends, San Diego, CA, AEB), saguan egindako GFAParen aurkakoa (1:40; Merck Millipore), untxian egindako NG2-aren aurkakoa (1:200; Merck Millipore) edo arratoian egindako CD11b-aren aurkakoa (1:100; Merck Millipore). Hainbat garbiketaren ondoren, ahuntzean egindako 488 edo 594 fluoroforoekin konjugatutako antigorputz sekundarioak (1:400; Invitrogen, Carlsbad, CA, AEB) gehitu zitzaizkien ehunei, antigorputz primarioak detektatu ahal izateko. Antigorputz sekundarioekin batera, Hoechst $33.258(5 \mu \mathrm{g} / \mathrm{mL}$; Sigma-Aldrich) gehitu zen kromatina markatzeko. Azkenik, ehunak Glycergel-a (Dako, Carpinteria, CA, AEB) erabiliz estali ziren. Esperimentu bakoitzean, antigorputz sekundarioarekin inkubatutako kontrol negatiboak gehitu genituen soilik, antigorputz primarioen espezifikotasuna egiaztatzeko.

\subsubsection{Irudien analisia}

Ehun-sekzioen argazkiak saio berean atera ziren, Axiocam MRc5 kamera digital bati lotutako Zeiss Axioplan 2 mikroskopio bat erabiliz (Zeiss, Oberkochen, Alemania). Desmielinizazioa eta hanturazko erantzuna (zelula glialen erreaktibitatea) ebaluatzeko, 2 argazki atera ziren 40X objektiboa gorputz kailukararen erdialdean jarrita.

Mielinaren kaltea ebaluatzeko, LFB eta MBP markaketak 0tik 4ra puntuatu ziren: 0 da desmielinizazio totala, eta 4 , mielina normala. 
Immunohistokimia bidez egindako markaketak ebaluatzeko, fluoreszentziazko mikroskopioaren intentsitatea kontrol negatiboetan seinalerik ikusten ez zen puntuan ezarri zen. Zelula glialen immunomarkaketa Image $J$ softwarea erabiliz kuantifikatu zen. GFAParen kasuan, markatutako area 16 bit-era bihurtutako irudietan neurtu, eta gorputz kailukararen area totalaz zatituz kalkulatu zen (markatutako area/area totala). Mikroglia/ makrofagoen kasuan, CD11 $\mathrm{b}^{+}$zelulak banan-banan zenbatu, eta dentsitatea gorputz kailukararen milimetro karratuko adierazi zen (zelula totalak/ $\mathrm{mm}^{2}$ ). Analisi guztiak gutxienez 4 saguz osatutako taldeetan egin ziren.

\subsection{Analisi estatistikoa}

Datuak batezbestekoa \pm errore estandarra (SEM) eran irudikatu dira, eta $n$-ak laginaren tamaina adierazten du (animalia kopurua). Analisi estatistikoak GraphPad Prism 6-aren 5.0 bertsioa erabiliz egin ziren (GraphPad Software Inc. San Diego, CA, AEB). Barra moduan adierazitako datu histologikoak, normaltasun-testa aplikatu ondoren, parekatu gabeko Student-en $t$ testarekin edo Mann Whitney $U$ testarekin aztertu ziren. Kasu guztietan, $<0,05 p$ balioak estatistikoki adierazgarritzat jo ziren.

\section{EMAITZAK}

\subsection{ABHD6 entzima inhibitzeak ez du birmielinizazio-prozesua bizkortzen}

Hainbat ikerketaren arabera, 2-AG endokanabinoidearen hidrolisia mekanismo desberdinen bitartez inhibitzeak gaitasuna du birmielinizazioa eta desmielinizatutako axoien berreskuratzea eragiteko [21, 40, 45]. Gure aurretiko aurkikuntzen ondoren [37, 38], aztertu nahi izan genuen ea zer ahalmen zuen ABHD6-a inhibitzeak kuprizonak eragindako desmielinizazioaren ondorengo mielinaren birsortzea bultzatzeko. Helburu horrekin, saguei 6 astez kuprizona eman zitzaien, eta, jarraian, bi astez, janari arruntera itzuli ziren, birmielinizazioa eragiteko/sustatzeko.

Kuprizona kendu eta hurrengo egunetik hasita, egunero KT182 inhibitzailearekin $(2 \mathrm{mg} / \mathrm{kg})$ edo eramaile soilarekin tratatu genituen animaliak (1. irudia A). LFBz eta MBPz markatutako gorputz kailukaran itsu-itsuka eginiko azterketek mielinaren birsortze partziala erakutsi zuten kuprizona kendu eta bi astez eramailearekin tratatu ziren saguetan $(* p<0,05$ kuprizonarekin 6 astez tratatu ziren saguekin konparatuz) (1. irudia B eta C). Hala ere, KT182 inhibitzailearekin tratatutako saguek ez zuten eramailearekin tratatutakoek baino hobekuntza eraginkorragorik agertu. Aurkikuntza horrek ABHD6-aren blokeoa gorputz kailukarako birmielinizazioa bizkortzeko gai ez dela iradokitzen du (1. irudia B eta C). 
A

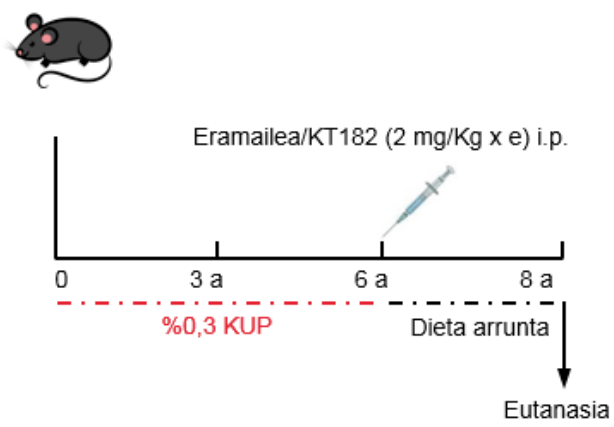

B

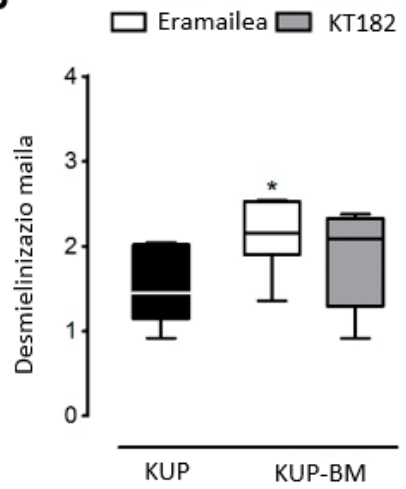

C
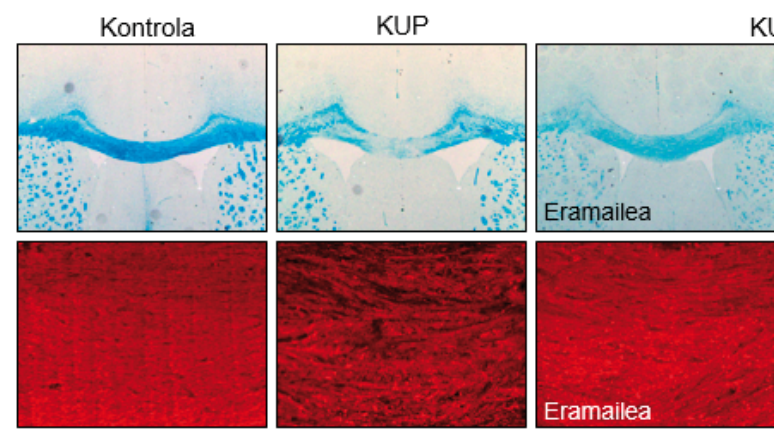

KUP-BM
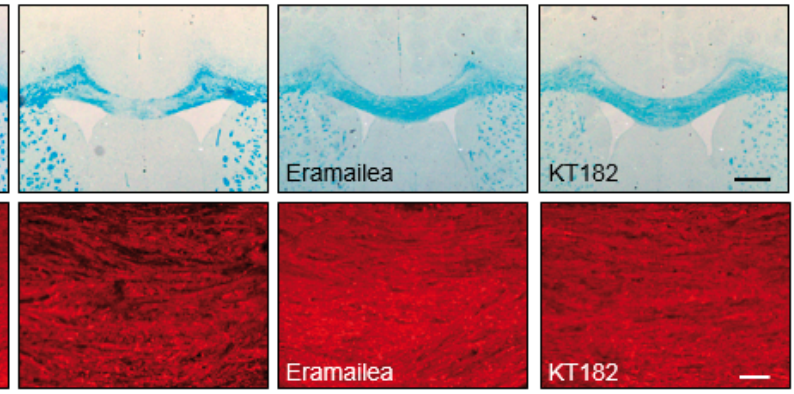

1. irudia. ABHD6-ren blokeoa ez da gai birmielinizazio-prozesua bizkortzeko kuprizonaren animalia-ereduan. (A) 6 astez kuprizonarekin tratatutako sagu guztien artean, ausaz talde bi birmielinizazio-fasean KT182-arekin ( $2 \mathrm{mg} / \mathrm{kg}$ ) edo eramailearekin tratatzeko aukeratu ziren. (C) LFB (goian) eta MBP (behean) markaketen analisiak (B) kuprizonarekin 6 astez tratatutako saguek gorputz kailukara desmielinizatuta zutela $(n=5$ sagu $)$ eta 2 astez janari arruntera itzultzean mielinaren birsortze partziala gertatu zela erakusten du. Itsu-itsuka eginiko LFB eta MBP markaketen puntuazioak ez du ezberdintasun esanguratsurik erakusten KT182-arekin edo eramailearekin tratatutako animalien artean $(n=6$ sagu). Eskala barrak: $500 \mu \mathrm{m}$ (LFB) eta $50 \mu \mathrm{m}$ (MBP).

Kuprizonak eragindako desmielinizazio primarioan, KT182-aren bidezko tratamenduak mikroglien eta astrozitoen erreaktibotasuna murrizteko gaitasuna erakusten du [37]. Emaitza horietan oinarrituz, zentzuzko hurrengo pausoa inhibitzaile horrek birmielinizazio-fasean zelula mota horietan izan ditzakeen efektuak aztertzea da. Kasu horretan, CD11 b ${ }^{+}$eta $\mathrm{GFAP}^{+}$zelulen erreaktibitateari dagokionez, ez genuen aldaketa esanguratsurik atzeman KT182-arekin tratatutako saguen eta eramailearekin tratatu- 
takoen artean gorputz kailukaretan (2. irudia A eta B). Aurkikuntza horien guztien arabera, ABHD6-aren inhibizioak ez dirudi etorkizun handiko estrategia mielinaren berreskuratzea bultzatzeko ezta gliosia eta hantura murrizteko ere.
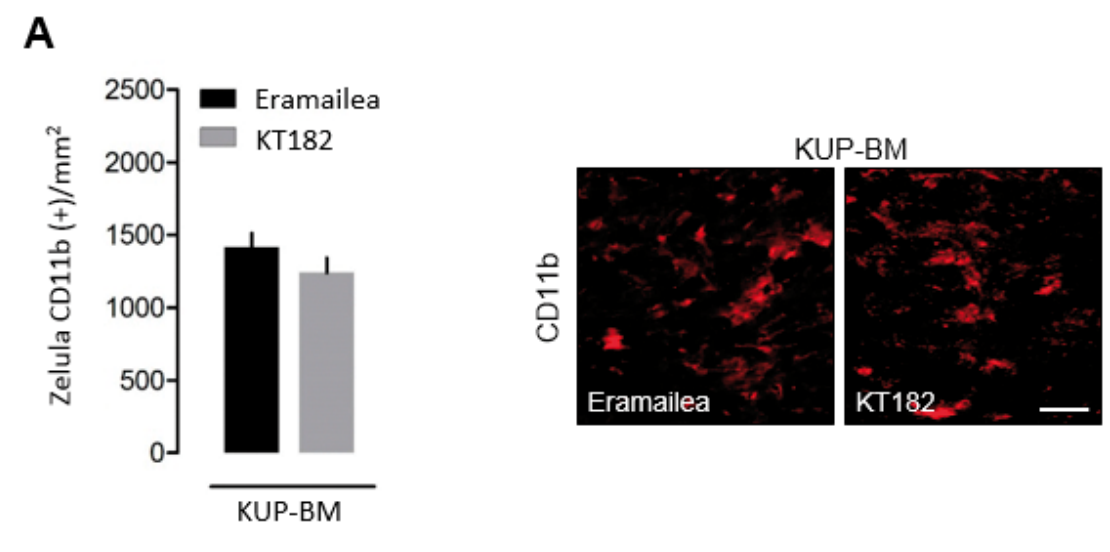

B
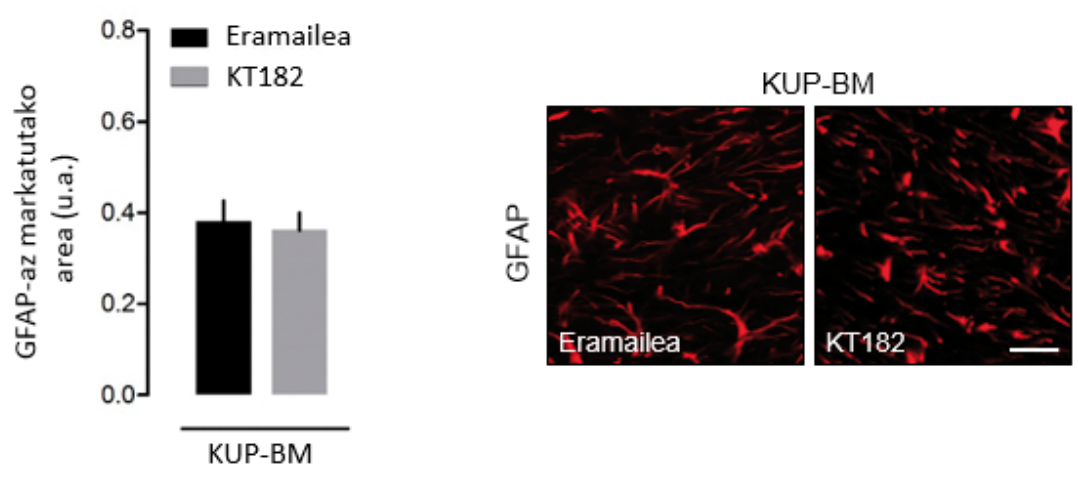

2. irudia. ABHD6-a inhibitzeak ez du astrozito eta mikroglien erreaktibotasuna

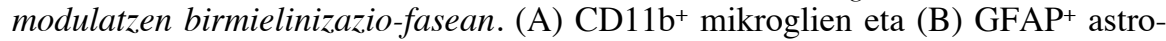
zitoen ebaluazioa KT182 $(2 \mathrm{mg} / \mathrm{kg})$ edo eramailearekin tratatutako saguen gorputz kailukaran $(n=5-6$ sagu). Kuantifikazioen arabera, hobetze-fasean, KT182 inhibitzaileak ez du eraginik zelula horietan. Eskala barrak: $25 \mu \mathrm{m}$.

\section{EZTABAIDA}

Ikerketa-lan honetan, kuprizonan oinarritutako animalia-eredua erabiliz EAren testuinguruan ABHD6 entzima inhibitzeak mielinaren konponketarako izan dezakeen baliagarritasun terapeutikoa aztertu dugu. Gurea- 
ren aurretiko aurkikuntzek barrera hematoentzefalikoa zeharkatzeko gai den KT182 inhibitzailea kuprizonak eragindako mielina-galera eta hanturazko erantzuna murrizteko gai dela erakusten dute [37]. Lan honen emaitzen arabera, berriz, konposatu hori ez da gai kuprizonaren administrazioaren osteko birmielinizazio-prozesua bizkortzeko, ezta hanturazko erantzuna murrizteko ere.

Kuprizonaren animalia-ereduan KT182 inhibitzailearen administrazio profilaktikoak mielinaren galera murrizten du [37]. Efektu onuragarri horrek bat dator MAGL entzimaren inhibizioak kuprizona, EAE eta TMEV ereduetan dituen eragin babesleekin [20, 44, 45]. ABHD6-a inhibitzearen onurak erlazionatuta egon litezke entzima horrek animalia-eredu horretan 2-AG guztiaren proportzio altuago bat hidrolizatzeko izan dezakeen gaitasunarekin, hantura-prozesuetan lehenago deskribatu den bezala [36]. Ildo horretan, MAGLaren inhibizioak birmielinizazioa bultzatzeko gaitasuna duela ikusita [45], ABHD6-aren inhibizioak antzeko onurak izan litzakeela pentsatzea logikoa da.

Espero bezala [54], kuprizona dietatik kentzeak berezko birmielinizazio partziala eragin zuen gorputz kailukaran. KT182 inhibitzailearen administrazioak, aitzitik, ez zuen inolako eraginik izan birmielinizazio-mailan. Birmielinizazioa arrakastatsua izateko, OPCen diferentziazioa gertatu behar da. Horri dagokionez, nahiz eta kultibatutako oligodendrozitoek Abhd6 genearen adierazpen-maila altuagoak izan Magl genearenak baino, in vitro, KT182-a ez da gai OPCak oligodendrozito heldu bihurtzeko diferentziazioprozesua bultatzeko, MAGL entzimaren inhibizioa bezala [37]. Birmielinizazio-esperimentuak egiaztatzen du ABHD6-aren inhibizioa ez dela gai oligodendroglia modulatzeko ezta in vivo ere. Itxurazko desadostasun horren arrazoia, oligodendrozitoetan, proteinaren adierazpen-mailak 2-AG-a hidrolizatzeko gaitasunarekin bat ez egitea izan daiteke. Hain zuzen ere, jakina da NSZn ABHD6-ak 2-AG-aren hidrolisian duen betebeharra MAGL entzimarena baino askoz txikiagoa dela [34].

Birmielinizazioa bultzatzeko beste estrategia bat endokanabinoideen bitartez hanturazko erantzuna murriztean datza. Hobeto esanda, ikusi da 2-AG-aren bidezko seinalizazioak mikroglia zelulen konponketaren aldeko fenotipoa eragiten duela, mielinaren birsortzea bultzatuz [46, 55]. Horri dagokionez, KT182-aren administrazio profilaktikoak mikroglien eta astroztioen hanturazko erantzuna murrizten zuela ikusi genuen [37]. Horrek iradokitzen du 2-AG-aren mailen igoerak hantura modulatzeko izan dezakeen ahalmenaren ondorio izan daitekeela mielinaren babesa. Aldiz, ABHD6 entzimaren inhibizioak ez zuen inolako efekturik izan hanturazko erantzunean birmielinizazio-fasean. Hain zuzen ere, mikrogliek eta astrozitoek erreaktibotasun berdina zutela antzeman genion, eramailearekin tratatutako animalia taldeak eta KT182-arekin tratatutakoak alderatzean. Baliteke hanturazko erantzun zehatzaren arabera mikrogliek eta astrozitoek 2-AG-aren 
kopuru ezberdina hidrolizatzea ABHD6 entzimaren bidez; horrela, testuinguruaren arabera, baliteke ABHD6-a inhibitzeak ez izatea 2-AG-aren mailak igotzeko gaitasunik. Beste aukera bat da kanabinoide-hartzaileen erabilgarritasuna edota adierazpen-mailak ezberdina izatea desmielinizazio-fase ezberdinetan; beraz, hartzaile horiek ez dira, nonbait ere, modu eraginkorrean aktibatzen KT182-ak eragiten duen 2-AG mailen igoerarekin. Gure emaitzek, nolanahi ere, onura eraginkorra lortzekotan gaixotasunaren lehen faseetan ABHD6-a inhibitu beharra iradokitzen dute.

Horrela, ABHD6-aren KT182 inhibitzailea birmielinizazioa bultzatu edo bizkortzeko gai ez dela ikusi dugu. Aurkikuntza horrek egiaztatu egiten $\mathrm{du}$, beraz, ABHD6-aren inhibitzaileak, in vivo, ez duela zelula oligodendroglialak modulatzeko gaitasunik. Bestalde, KT182-a, hobetze-fasean era terapeutikoan administratuta, ez da gai izaten desmielinizatutako gorputz kailukarako hantura murrizteko. Horrek kontrastatu egiten du KT182-ak era profilaktikoan administratuz gero eragiten duen hantura-murrizketarekin, eta mielina babestu ahal izateko ABHD6-aren inhibizio goiztiarra beharrezkoa dela iradokitzen. Emaitza horien guztien arabera, ABHD6 entzima hanturazko ingurune batean inhibitzeak ez duela mielinaren birsortzea bultzatzeko ahalmenik ondoriozta dezakegu.

\section{ESKER ONAK}

Artikulu hau ahalbidetu duen finantziazioa: Eusko Jaurlaritzako 2014-2015 ikasturteko doktoreak ez diren ikertzaileak prestatzeko Doktoratu Aurreko Programako Laguntza (AM) eta 2016-2017 ikasturteko ikertzaile doktoreentzako Doktoratu Ondoko Hobekuntza Programarako Laguntza (ABC); Ekonomia eta Lehiakortasun Ministerioaren (SAF2013-45084-R eta SAF2016-75292-R) laguntzak; Eusko Jaurlaritzaren (IT702-13) laguntza; CIBERNEDren (PRY-15 -404) laguntza; ARSEP fundazioa; WOP fundazioa.

\section{BIBLIOGRAFIA}

[1] COMPSTON, A. and COLES, A. 2008 «Multiple sclerosis». Lancet, 372, 1502-1517.

[2] WEINER, H. L. 2004. «Multiple sclerosis is an inflammatory T-cell-mediated autoimmune disease». Arch Neurol, 61, 1613-1615.

[3] GRIGORIADIS, N., VAN PESCH, V. and GROUP, P. 2015. «A basic overview of multiple sclerosis immunopathology». Eur J Neurol, 22 Suppl 2, 3-13.

[4] LUCCHINETTI, C., BRÜCK, W., PARISI, J., SCHEITHAUER, B., RODRIGUEZ, M. and LASSMANN, H. 2000. «Heterogeneity of multiple sclerosis lesions: implications for the pathogenesis of demyelination». Ann Neurol, 47, 707-717. 
[5] BARNETT, M. H. and PRINEAS, J. W. 2004. «Relapsing and remitting multiple sclerosis: pathology of the newly forming lesion». Ann Neurol, 55, 458-468.

[6] CHANG, A., STAUGAITIS, S. M., DUTTA, R., BATT, C. E., EASLEY, K. E., CHOMYK, A. M., YONG, V. W., FOX, R. J., KIDD, G. J. and TRAPP, B. D. 2012. «Cortical remyelination: a new target for repair therapies in multiple sclerosis». Ann Neurol, 72, 918-926.

[7] FRANKLIN, R. J. M. and FFRENCH-CONSTANT, C. 2017. «Regenerating CNS myelin - from mechanisms to experimental medicines». Nat Rev Neurosci, 18, 753-769.

[8] KREMER, D., AKKERMANN, R., KÜRY, P. and DUTTA, R. 2018. «Current advancements in promoting remyelination in multiple sclerosis». Mult Scler, 25, 7-14.

[9] FRANKLIN, R. J. 2002. «Why does remyelination fail in multiple sclerosis? ». Nat Rev Neurosci, 3, 705-714.

[10] KIPP, M., NYAMOYA, S., HOCHSTRASSER, T. and AMOR, S. 2017. «Multiple sclerosis animal models: a clinical and histopathological perspective». Brain Pathol, 27, 123-137.

[11] MATSUDA, L. A., LOLAIT, S. J., BROWNSTEIN, M. J., YOUNG, A. C. and BONNER, T. I. 1990. «Structure of a cannabinoid receptor and functional expression of the cloned cDNA». Nature, 346, 561-564.

[12] MUNRO, S., THOMAS, K. L. AND ABU-SHAAR, M. 1993. «Molecular characterization of a peripheral receptor for cannabinoids». Nature, $\mathbf{3 6 5}$, 61-65.

[13] MARSICANO, G. and LUTZ, B. 1999. «Expression of the cannabinoid receptor CB1 in distinct neuronal subpopulations in the adult mouse forebrain». Eur J Neurosci, 11, 4213-4225.

[14] KAWAMURA, Y., FUKAYA, M., MAEJIMA, T., YOSHIDA, T., MIURA, E., WATANABE, M., OHNO-SHOSAKU, T. and KANO, M. 2006. «The $\mathrm{CB} 1$ cannabinoid receptor is the major cannabinoid receptor at excitatory presynaptic sites in the hippocampus and cerebellum». J Neurosci, 26, 2991-3001.

[15] GUTIÉRREZ-RODRÍGUEZ, A., PUENTE, N., ELEZGARAI, I., RUEHLE, S., LUTZ, B., REGUERO, L., GERRIKAGOITIA, I., MARSICANO, G. and GRANDES, P. 2017. "Anatomical characterization of the cannabinoid CB1 receptor in cell-type-specific mutant mouse rescue models». J Comp Neuro, 525, 302-318.

[16] KATONA, I. AND FREUND, T. F. 2012. «Multiple functions of endocannabinoid signaling in the brain». Annu Rev Neurosci, 35, 529-558.

[17] HAN, J., KESNER, P., METNA-LAURENT, M., DUAN, T., XU, L., GEORGES, F., KOEHL, M., ABROUS, D. N., MENDIZABAL-ZUBIAGA, J., GRANDES, P., LIU, Q., BAI, G., WANG, W., XIONG, L., REN, W., MARSICANO, G. and ZHANG, X. 2012. «Acute cannabinoids impair working memory through astroglial CB1 receptor modulation of hippocampal LTD». Cell, 148, 1039-1050. 
[18] GUTIÉRREZ-RODRÍGUEZ, A., BONILLA-DEL RÍO, I., PUENTE, N., GÓMEZ-URQUIJO, S. M., FONTAINE, C. J., EGAÑA-HUGUET, J., ELEZGARAI, I., RUEHLE, S., LUTZ, B., ROBIN, L. M., SORIA-GÓMEZ, E., BELLOCCHIO, L., PADWAL, J. D., VAN DER STELT, M., MENDIZABAL-ZUBIAGA, J., REGUERO, L., RAMOS, A., GERRIKAGOITIA, I., MARSICANO, G. and GRANDES, P. 2018. «Localization of the cannabinoid type-1 receptor in subcellular astrocyte compartments of mutant mouse hippocampus». Glia,66, 1471-1431.

[19] STELLA, N. 2010. «Cannabinoid and cannabinoid-like receptors in microglia, astrocytes, and astrocytoma»s. Glia, 58, 1017-1030.

[20] BERNAL-CHICO, A., CANEDO, M., MANTEROLA, A., VICTORIA SÁNCHEZ-GÓMEZ, M., PÉREZ-SAMARTÍN, A., RODRÍGUEZ-PUERTAS, R., MATUTE, C. and MATO, S. 2015. «Blockade of monoacylglycerol lipase inhibits oligodendrocyte excitotoxicity and prevents demyelination in vivo». Glia, 63, 163-176.

[21] GOMEZ, O., AREVALO-MARTIN, A., GARCIA-OVEJERO, D., ORTEGA-GUTIERREZ, S., CISNEROS, J. A., ALMAZAN, G., SÁNCHEZ-RODRIGUEZ, M. A., MOLINA-HOLGADO, F. and MOLINA-HOLGADO, E. 2010. «The constitutive production of the endocannabinoid 2-arachidonoylglycerol participates in oligodendrocyte differentiation». Glia, 58, 19131927.

[22] HOWLETT, A. C. 2002. «The cannabinoid receptors». Prostaglandins Other Lipid Mediat, 68-69, 619-631.

[23] BERDYSHEV, E. V. 2000. «Cannabinoid receptors and the regulation of immune response». Chem Phys Lipids, 108, 169-190.

[24] ATWOOD, B. K. and MACKIE, K. 2010. «CB2: a cannabinoid receptor with an identity crisis». Br J Pharmacol, 160, 467-479.

[25] MECHA, M., CARRILLO-SALINAS, F. J., FELIÚ, A., MESTRE, L. and GUAZA, C. 2016. «Microglia activation states and cannabinoid system: Therapeutic implications». Pharmacol The,. 166, 40-55.

[26] DEVANE, W. A., HANUS, L., BREUER, A., PERTWEE, R. G., STEVENSON, L. A., GRIFFIN, G., GIBSON, D., MANDELBAUM, A., ETINGER, A. and MECHOULAM, R. 1992. «Isolation and structure of a brain constituent that binds to the cannabinoid receptor». Science, 258, 1946-1949.

[27] SUGIURA, T., KONDO, S., SUKAGAWA, A., NAKANE, S., SHINODA, A., ITOH, K., YAMASHITA, A. and WAKU, K. 1995. «2-Arachidonoylglycerol: a possible endogenous cannabinoid receptor ligand in brain». Biochem Biophys Res Commun, 215, 89-97.

[28] BISOGNO, T., HOWELl, F., WILliAMS, G., MINASSI, A., CASCIO, M. G., LIGRESTI, A., MATIAS, I., SCHIANO-MORIELLO, A., PAUL, P., WILLIAMS, E. J., GANGADHARAN, U., HOBBS, C., DI MARZO, V. and DOHERTY, P. 2003. "Cloning of the first sn1-DAG lipases points to the spatial and temporal regulation of endocannabinoid signaling in the brain». J Cell Biol, 163, 463-468. 
[29] BISOGNO, T. 2008. «Endogenous cannabinoids: structure and metabolism». J Neuroendocrinol, 20 Suppl 1, 1-9.

[30] CRAVATT, B. F., GIANG, D. K., MAYFIELD, S. P., BOGER, D. L., LERNER, R. A. and GILULA, N. B. 1996. «Molecular characterization of an enzyme that degrades neuromodulatory fatty- acid amides». Nature, 384, 83-87.

[31] DINH, T. P., FREUND, T. F. and PIOMELLI, D. 2002. «A role for monoglyceride lipase in 2-arachidonoylglycerol inactivation». Chem Phys Lipids, 121, 149-158.

[32] SAVINAINEN, J. R., SAARIO, S. M. and LAITINEN, J. T. 2012 «The serine hydrolases MAGL, ABHD6 and ABHD12 as guardians of 2-arachidonoylglycerol signalling through cannabinoid receptors». Acta Physiol (Oxf), 204, 267-276.

[33] LUTZ, B., MARSICANO, G., MALDONADO, R. and HILLARD, C. J. 2015. «The endocannabinoid system in guarding against fear, anxiety and stress». Nat Rev Neurosci, 16, 705-718.

[34] BLANKMAN, J. L., SIMON, G. M. and CRAVATT, B. F. 2007. «A comprehensive profile of brain enzymes that hydrolyze the endocannabinoid 2-arachidonoylglycerol». Chem Biol, 14, 1347-1356.

[35] MARRS, W. R., BLANKMAN, J. L., HORNE, E. A., THOMAZEAU, A., LIN, Y. H., COY, J., BODOR, A. L., MUCCIOLI, G. G., HU, S. S., WOODRUFF, G., FUNG, S., LAFOURCADE, M., ALEXANDER, J. P., LONG, J. Z., LI, W., XU, C., MÖLLER, T., MACKIE, K., MANZONI, O. J., CRAVATT, B. F. and STELLA, N. 2010. «The serine hydrolase ABHD6 controls the accumulation and efficacy of 2-AG at cannabinoid receptors». Nat Neurosci, 13, 951-957.

[36] POURSHARIFI, P., MADIRAJU, S. R. M. and PRENTKI, M. 2017. «Monoacylglycerol signalling and ABHD6 in health and disease». Diabetes Obes Metab, 19 Suppl 1, 76-89.

[37] MANTEROLA, A., BERNAL-CHICO, A., CIPRIANI, R., CANEDO-ANTELO, M., MORENO-GARCÍA, Á., MARTÍN-FONTECHA, M., PÉREZCERDÁ, F., SÁNCHEZ-GÓMEZ, M. V., ORTEGA-GUTIÉRREZ, S., BROWN, J. M., HSU, K. L., CRAVATT, B., MATUTE, C. and MATO, S. 2018. «Deregulation of the endocannabinoid system and therapeutic potential of ABHD6 blockade in the cuprizone model of demyelination». Biochem Pharmacol, 157, 189-201.

[38] MANTEROLA, A., BERNAL-CHICO, A., CIPRIANI, R., RUIZ, A., PÉREZSAMARTÍN, A., MORENO-RODRÍGUEZ, M., HSU, K. L., CRAVATT, B. F., BROWN, J. M., RODRÍGUEZ-PUERTAS, R., MATUTE, C. and MATO, S. 2018. «Re-examining the potential of targeting ABHD6 in multiple sclerosis: Efficacy of systemic and peripherally restricted inhibitors in experimental autoimmune encephalomyelitis». Neuropharmacology, 141, 181-191.

[39] CONSROE, P., MUSTY, R., REIN, J., TILLERY, W. and PERTWEE, R. 1997. «The perceived effects of smoked cannabis on patients with multiple sclerosis». Eur Neurol, 38, 44-48. 
[40] ARÉVALO-MARTÍN, A., VELA, J. M., MOLINA-HOLGADO, E., BORRELL, J. and GUAZA, C. 2003. «Therapeutic action of cannabinoids in a murine model of multiple sclerosis». J Neurosci, 23, 2511-2516.

[41] PAlazUelos, J., DAVOUSt, N., JUlien, B., HATTERER, E., AGUADO, T., MECHOULAM, R., BENITO, C., ROMERO, J., SILVA, A., GUZMÁN, M., NATAF, S. and GALVE-ROPERH, I. 2008. «The CB(2) cannabinoid receptor controls myeloid progenitor trafficking: involvement in the pathogenesis of an animal model of multiple sclerosis». J Biol Chem, 283, 13320-13329.

[42] CABRANES, A., VENDEROVA, K., DE LAGO, E., FEZZA, F., SÁNCHEZ, A., MESTRE, L., VALENTI, M., GARCÍA-MERINO, A., RAMOS, J. A., DI MARZO, V. and FERNÁNDEZ-RUIZ, J. 2005. «Decreased endocannabinoid levels in the brain and beneficial effects of agents activating cannabinoid and/or vanilloid receptors in a rat model of multiple sclerosis». Neurobiol Dis, 20, 207-217.

[43] MARESZ, K., PRYCE, G., PONOMAREV, E. D., MARSICANO, G., CROXFORD, J. L., SHRIVER, L. P., LEDENT, C., CHENG, X., CARRIER, E. J., MANN, M. K., GIOVANNONI, G., PERTWEE, R. G., YAMAMURA, T., BUCKLEY, N. E., HILLARD, C. J., LUTZ, B., BAKER, D. and DITTEL, B. N. 2007. «Direct suppression of CNS autoimmune inflammation via the cannabinoid receptor $\mathrm{CB} 1$ on neurons and $\mathrm{CB} 2$ on autoreactive T cells». Nat Med, 13, 492-497.

[44] HERNÁNDEZ-TORRES, G., CIPRIANO, M., HEDÉN, E., BJÖRKLUND, E., CANALES, Á., ZIAN, D., FELIÚ, A., MECHA, M., GUAZA, C., FOWLER, C. J., ORTEGA-GUTIÉRREZ, S. and LÓPEZ-RODRÍGUEZ, M. L. 2014. «A reversible and selective inhibitor of monoacylglycerol lipase ameliorates multiple sclerosis». Angew Chem Int Ed Engl, 53, 13765-13770.

[45] FELIÚ, A., BONILLA DEL RÍO, I., CARRILLO-SALINAS, F. J., HERNÁNDEZ-TORRES, G., MESTRE, L., PUENTE, N., ORTEGA-GUTIÉRREZ, S., LÓPEZ-RODRÍGUEZ, M. L., GRANDES, P., MECHA, M. and GUAZA, C. 2017. «2-Arachidonoylglycerol Reduces Proteoglycans and Enhances Remyelination in a Progressive Model of Demyelination». $J$ Neurosci, 37, 8385-8398.

[46] MECHA, M., FELIÚ, A., MACHÍN, I., CORDERO, C., CARRILLO-SALINAS, F., MESTRE, L., HERNÁNDEZ-TORRES, G., ORTEGA-GUTIÉRREZ, S., LÓPEZ-RODRÍGUEZ, M. L., DE CASTRO, F., CLEMENTE, D. and GUAZA, C. 2018. «2-AG limits Theiler's virus induced acute neuroinflammation by modulating microglia and promoting MDSCs». Glia, 66, 1447-1463.

[47] SCHLOSBURG, J. E., BLANKMAN, J. L., LONG, J. Z., NOMURA, D. K., PAN, B., KINSEY, S. G., NGUYEN, P. T., RAMESH, D., BOOKER, L., BURSTON, J. J., THOMAS, E. A., SELLEY, D. E., SIM-SELLEY, L. J., LIU, Q. S., LICHTMAN, A. H. and CRAVATT, B. F. 2010. «Chronic monoacylglycerol lipase blockade causes functional antagonism of the endocannabinoid system». Nat Neurosci, 13, 1113-1119. 
[48] ALHOUAYEK, M., MASQUELIER, J., CANI, P. D., LAMBERT, D. M. and MUCCIOLI, G. G. 2013. «Implication of the anti-inflammatory bioactive lipid prostaglandin D2-glycerol ester in the control of macrophage activation and inflammation by ABHD6». Proc Natl Acad Sci U S A, 110, 17558-17563.

[49] NAYDENOV, A. V., HORNE, E. A., CHEAH, C. S., SWINNEY, K., HSU, K. L., CAO, J. K., MARRS, W. R., BLANKMAN, J. L., TU, S., CHERRY, A. E., FUNG, S., WEN, A., LI, W., SAPORITO, M. S., SELLEY, D. E., CRAVATT, B. F., OAKLEY, J. C. and STELLA, N. 2014. «ABHD6 blockade exerts antiepileptic activity in PTZ-induced seizures and in spontaneous seizures in R6/2 mice». Neuron, 83, 361-371.

[50] LONG, J. Z., LI, W., BOOKER, L., BURSTON, J. J., KINSEY, S. G., SCHLOSBURG, J. E., PAVÓN, F. J., SERRANO, A. M., SELLEY, D. E., PARSONS, L. H., LICHTMAN, A. H. and CRAVATT, B. F. 2009. «Selective blockade of 2-arachidonoylglycerol hydrolysis produces cannabinoid behavioral effects». Nat Chem Biol, 5, 37-44.

[51] WEN, J., RIBEIRO, R., TANAKA, M. and ZHANG, Y. 2015. "Activation of CB2 receptor is required for the therapeutic effect of ABHD6 inhibition in experimental autoimmune encephalomyelitis». Neuropharmacology, 99, 196-209.

[52] TANAKA, M., MORAN, S., WEN, J., AFFRAM, K., CHEN, T., SYMES, A. J. and ZHANG, Y. 2017. «WWL70 attenuates PGE2 production derived from 2-arachidonoylglycerol in microglia by ABHD6-independent mechanism». J Neuroinflammation, 14, 1-15.

[53] HSU, K. L., TSUBOI, K., CHANG, J. W., WHITBY, L. R., SPEERS, A. E., PUGH, H. and CRAVATT, B. F. 2013. «Discovery and optimization of piperidyl-1,2,3-triazole ureas as potent, selective, and in vivo-active inhibitors of $\alpha / \beta$-hydrolase domain containing 6 (ABHD6) ». J Med Chem, 56, 8270-8279.

[54] SKRIPULETZ, T., GUDI, V., HACKSTETTE, D. and STANGEL, M. 2011. «De- and remyelination in the CNS white and grey matter induced by cuprizone: the old, the new, and the unexpected». Histol Histopathol, 26, 1585-1597.

[55] ALHOUAYEK, M., MASQUELIER, J. and MUCCIOLI, G. G. 2014. «Controlling 2-arachidonoylglycerol metabolism as an anti-inflammatory strategy». Drug Discov Today, 19, 295-304. 